\title{
Review of Survey activities 2008
}

Edited by

Ole Bennike, Adam A. Garde and W. Stuart Watt 


\section{Geological Survey of Denmark and Greenland Bulletin 17}

\section{Keywords}

Geological Survey of Denmark and Greenland, survey organisations, current research, Denmark, Greenland.

\section{Cover photographs from left to right}

1. Inspection of cores in Jameson Land, East Greenland. Photo: John Boserup.

2. Field work in West Greenland. Photo: Denis Schlatter.

3. Investigations and sampling of an outcrop at Conde, Bahia, Brazil. Photo: Peter Japsen.

4. Field experiments with remediation of contaminated soil in Vadsby, west of Copenhagen. Photo: Knud Erik S. Klint.

\section{Frontispiece: facing page}

Visit at the automatic weather station 'Lower Nuuk' on 30 July 2008 for data retrieval and maintenance. The station is located on the glacier Qamanaarsuup Sermia near the margin of the Greenland ice sheet, east of Godthåbsfjord $\left(64^{\circ} 29^{\prime} \mathrm{N}, 49^{\circ} 31^{\prime} \mathrm{W}\right)$. It collects weather information and data about the local ablation and was established in 2007 as part of the Promice project (www.promice.org). Photo: Søren Nielsen.

Chief editor of this series: Adam A. Garde

Editorial board of this series: John A. Korstgård, Department of Earth Sciences, University of Aarhus; Minik Rosing, Geological Museum, University of Copenhagen; Finn Surlyk, Department of Geography and Geology, University of Copenhagen Scientific editors: Ole Bennike, Adam A. Garde and W. Stuart Watt Editorial secretaries: Jane Holst and Esben W. Glendal Referees: (DK = Denmark; numbers refer to first page of reviewed article): Anonymous (29, 29, 33, 45, 49, 77, 77, 81); Lars Christiansen, DK (41); Finn Dalhoff, DK (13); Gregers Dam, DK (53); Edward F. Duke, USA (69); Ida Fabricius, DK (17); Henrik Friis, DK (25); MarieJosé Gaillard, S (37); Ole Graversen, DK (81); Karen Hanghøj, USA (61); Bent Hasholt, DK (45); Jens Havskov, N (9); Ole Humlum, N (74); Paul Martin Holm, DK (61); Jens Konnerup-Madsen, DK (65); John A. Korstgård, DK (57); Nicolaj Krog Larsen, S (33); Poul-Henrik Larsen, DK (53); Christoph Mayer, G (74); Florence Mazier, S (37); Klaus Mosegaard, DK (9); John Myers, Australia (49); Allan Aasbjerg Nielsen, DK (69); Henrik Olsen, DK (41); Graham Pearson, UK (65); Asger Ken Pedersen, DK (57); Gunver Krarup Pedersen, DK (21); Jan Audun Rasmussen, DK (21); Martin Sønderholm, DK (25); Morten Gjetting Stage, DK (13); Ole V. Vejbæk, DK (17). Illustrations: Stefan Sølberg, with contributions from Benny M. Schark

Lay-out and graphic production: Henrik Klinge Pedersen and Annabeth Andersen

Printers: Schultz Grafisk, Albertslund, Denmark

Manuscripts submitted: 23 January - 27 March 2009

Final versions approved: 25 May 2009

Printed: 8 July 2009

ISSN 1603-9769 (Review of Survey activities)

ISSN 1604-8156 (Geological Survey of Denmark and Greenland Bulletin)

ISBN 978-87-7871-250-9

\section{Citation of the name of this series}

It is recommended that the name of this series is cited in full, viz. Geological Survey of Denmark and Greenland Bulletin. If abbreviation of this volume is necessary, the following form is suggested: Geol. Surv. Den. Green. Bull. 17, 84 pp.

\section{Available from}

Geological Survey of Denmark and Greenland (GEUS)

Øster Voldgade 10, DK-1350 Copenhagen K, Denmark

Phone: +45381420 00, fax: +45381420 50, e-mail: geus@geus.dk

(C) De Nationale Geologiske Undersøgelser for Danmark og Grønland (GEUS), 2009

For the full text of the GEUS copyright clause, please refer to www.geus.dk/publications/bull 


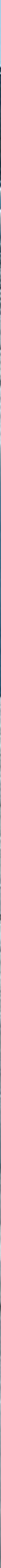




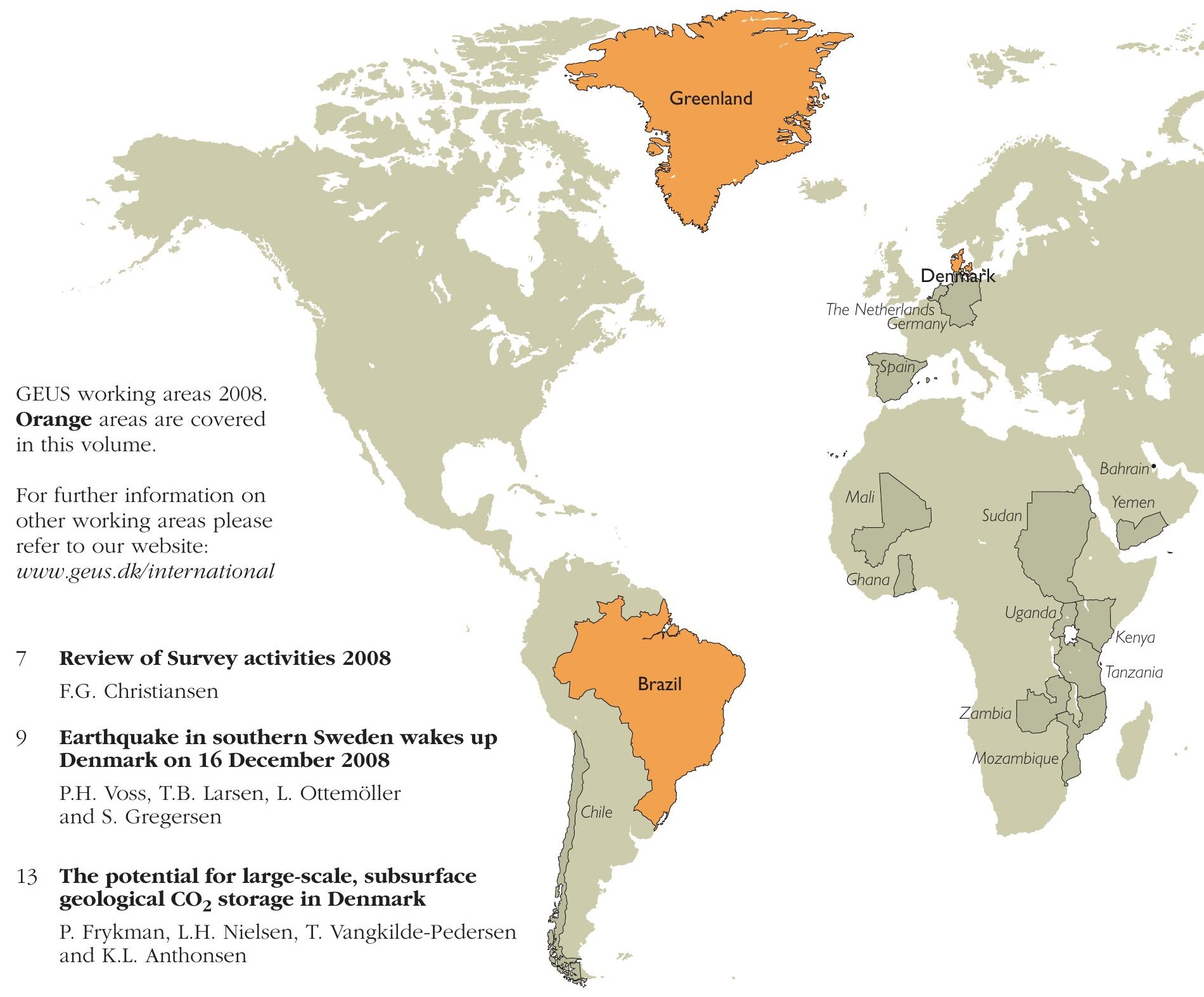

17 Increased oil recovery from Halfdan chalk by flooding with $\mathrm{CO}_{2}$-enriched water: a laboratory experiment

D. Olsen

21 Ladinian palynofloras in the NorwegianDanish Basin: a regional marker reflecting a climate change

S. Lindström, H. Vosgerau, S. Piasecki,

L.H. Nielsen, K. Dybkjær and M. Erlström

29 Structural development of Maglevandsfald: a key to understanding the glaciotectonic architecture of Møns Klint, SE Denmark

S.A.S. Pedersen and P. Gravesen

33 Fracture valleys in central Jylland - a neotectonic feature

P.R. Jakobsen and S.A.S. Pedersen

25 Fingerprinting sediments along the west coast of Jylland: interpreting provenance data

C. Knudsen, T. Kokfelt, T. Aagaard, J. Bartholdy and M. Pejrup

37 Soil erosion and land-use change during the last six millennia recorded in lake sediments of Gudme Sø, Fyn, Denmark

P. Rasmussen and J. Olsen 
53 Shallow core drilling and petroleum geology related field work in East and NorthEast Greenland 2008

J.A. Bojesen-Koefoed, M. Bjerager and S. Piasecki

57 The bedrock geology under the Inland Ice: the next major challenge for Greenland mapping

P.R. Dawes

61 Developing a 3-D model for the Skaergaard intrusion in East Greenland: constraints on structure, mineralisation and petrogenetic models

T.F.D. Nielsen, S.D. Olsen and B.M. Stensgaard

65 Diamonds and lithospheric mantle properties in the Neoproterozoic igneous province of southern West Greenland

A. Steenfelt, S.M. Jensen, T.F.D. Nielsen, K.K. Sand and K. Secher

69 Using spectral mixture analysis of hyperspectral remote sensing data to map lithology of the Sarfartoq carbonatite complex, southern West Greenland

E. Bedini and T. Tukiainen

41 Geophysical methods and data administration in Danish groundwater mapping

I. Møller, V.H. Søndergaard and F. Jørgensen

45 Water budget of Skærsø, a lake in south-east Jylland, Denmark: exchange between groundwater and lake water

B. Nilsson, P. Engesgaard, J. Kidmose, S. Karan, M.C. Looms and M.C.S. Frandsen

49 Geological observations in the southern West Greenland basement from Ameralik to Frederikshåb Isblink in 2008

N. Keulen, A. Scherstén, J.C. Schumacher,

T. Næraa and B.F. Windley
73 Glaciological investigations at the Malmbjerg mining prospect, central East Greenland

M. Citterio, R. Mottram, S.H. Larsen and A. Ahlstrøm

77 Holocene climate variability in southern Greenland: results from the Galathea 3 expedition

N. Nørgaard-Pedersen, N. Mikkelsen, M.D. Poulsen and A.S. Simonsen

81 Post-rift landscape development of northeast Brazil

J.M. Bonow, P. Japsen, P.F. Green, P.R. Cobbold, A.J. Pedreira, R. Lilletveit and D. Chiossi 



\title{
Review of Survey activities 2008
}

\author{
Flemming G. Christiansen \\ Deputy Director
}

Following a number of years with major changes of the scientific environment in Denmark and also within the management of the Geological Survey of Denmark and Greenland (GEUS), 2008 was a year of stability and consolidation, a situation that will hopefully continue. Many new projects have been initiated and many previous projects have been completed at a time with strong focus on GEUS' activities politically, commercially and from the media.

This sixth annual issue of Review of Survey activities describes selected projects that GEUS and its partners carry out in Denmark, Greenland and internationally. Together with the previous five published issues (also available at www.geus.dk), it provides a good overview of the Survey's many different types of research and advisory activities. It contains a total of 19 four-page papers: ten on Denmark, eight on Greenland and one on international work.

Geology was on the lips of most of the Danish population an early morning in December 2008 when one of the strongest earthquakes recorded in Scandinavia woke up hundreds of thousands of people in southern Sweden and on Sjælland. One paper in this issue describes the background and details of the earthquake, including input from the public that contacted GEUS through its website.

Reduction of the emission of $\mathrm{CO}_{2}$ is high on the political agenda in Denmark and internationally. One of the possibilities to reduce $\mathrm{CO}_{2}$ emission from large point sources is to use carbon capture and storage (CCS). The Danish subsurface has a high potential to store $\mathrm{CO}_{2}$, and structures such as the Vedsted structure in northern Jylland could be among the first dozen storage facilities utilised in Europe, and thereby become a key area for detailed research and monitoring for many years to come. The background for CCS and geological possibilities in Denmark are described in one paper.

Oil and gas exploration and production are still very important for the economy of Denmark, and GEUS has a strong emphasis on research within this field. Two papers concentrate on petroleum geology. One of them is based on laboratory flooding experiments and describes the possibility of increasing oil recovery from reservoirs in chalk using injection of $\mathrm{CO}_{2}$-enriched water; the other provides a detailed biostratigraphic correlation of the Late Triassic succession in the Norwegian-Danish Basin.

Most surface features in Denmark have been formed by glacial and coastal processes during the Quaternary. Several papers in this issue describe such processes; one of them demonstrates the use of sophisticated analytical techniques such as computer-controlled, scanning electron microscopy of heavy minerals and laser ablation, inductively coupled mass spectrometry of zircon grains to describe erosion and re-deposition of sand along the west coast of Jylland. The structural development of the famous Møns Klint geosite is dealt with in one paper, and the occurrence of neotectonic fracture valleys in central Jylland in another. A third paper describes soil erosion and land use change during the last six millennia as recorded in lake sediments from Gudme Sø on Fyn.

Groundwater mapping and management have a very high priority in Denmark. One paper describes the many different geophysical methods that are used in hydrogeological mapping, as well as the administration of the geophysical data that are archived in a major database hosted at GEUS. Another paper describes the exchange between lake water and groundwater of lake Skærsø in Jylland.

In 2008 there was a high level of field activities in Greenland. The two largest campaigns in southern West Greenland and eastern Greenland are described in individual papers. The West Greenland field work was a follow-up on earlier projects focused on updating previous maps and thereby creating a better understanding of the potential distribution of mineral occurrences. The field work in eastern Greenland is the start of a major oil industry sponsored programme that has been launched to support and promote petroleum exploration within the coming five-year period. It includes shallow core drilling.

One paper addresses a question often raised by scientists and explorers: what is the bedrock geology under the Inland Ice that covers $81 \%$ of the total area of Greenland? Available 
geological and geophysical data are shortly reviewed and ideas for future studies presented. Another paper introduces a 3-D modelling of one of the best studied intrusions in the world, the Paleocene Skaergaard intrusion in East Greenland. Identification of significant platinum group and gold occurrences in this intrusion has lead to detailed investigations and exploration drilling over many years. The last decade of diamond exploration in West Greenland has provided a wealth of data on the dykes of kimberlite and ultramafic lamprophyres that may host diamonds. One paper summarises new data on petrology and age distribution of the dykes that have important implications for future diamond exploration. In a large country like Greenland, use of remote sensing data is important and cost-effective in mapping and exploration. One paper presents an analysis of hyperspectral data from the Sarfartoq carbonatite complex in West Greenland. The paper illustrates that such data can be applied to mapping of individual rock types.
The most recent processes and climate development in Greenland are described in two papers of which one stresses the importance of applied glaciology for the exploitation of the Malmbjerg molybdenum deposit in East Greenland, because the site of a possible future mine is located between two glaciers. Future access to the mining site and removal of ore and waste rock are highly dependent on the movement of the glaciers. The second paper addresses Holocene climate variation and marine history in South Greenland, based on a number of samples collected in Bredefjord and Narsaq Sund during the Galathea 3 expedition.

A final paper on landscape development in Brazil employs the same methods of landscape mapping and apatite fission track analysis that were used to study the uplift history of the margins of Greenland and Scandinavia. 